\title{
Identification of Soil Transmitted Helminth Contamination on The Raw Vegetables in Warung Pecel Lele in Kebon Jeruk District, West Jakarta
}

\author{
Andrew Timothy Fane, Esther Sri Majawati ${ }^{*}$, Harro Harris Liman \\ Departemen Parasitologi, Fakultas Kedokteran Universitas Kristen Krida Wacana, Jl. Tanjung Duren Raya No.4, \\ Jakarta Barat 11470, Indonesia \\ *Corresponding author : esther.majawati@ukrida.ac.id
}

\begin{abstract}
ABSTRAK
Infeksi cacing usus banyak menimbulkan masalah kesehatan. Transmisi penularannya bisa terjadi melalui kontaminasi air, makanan atau melalui kulit. Sebagian infeksi cacing usus dapat terjadi melalui makan lalapan mentah yang seringkali disajikan di warung makan. Tujuan penelitian ini adalah mengetahui apakah lalapan mentah yang disajikan pada warung makan pecel lele di kecamatan Kebon Jeruk Jakarta terkontaminasi telur cacing Soil Transmitted Helminth dan mengetahui jenis cacing yang mengontaminasinya. Penelitian ini merupakan penelitian deskriptif dengan pendekatan cross sectional. Lalapan mentah diambil dari 25 warung makan pecel lele dan didapatkan sebanyak 74 sampel. Pemeriksaan sampel untuk menemukan telur cacing, dilakukan dengan metode sedimentasi. Hasil dari penelitian diketahui jumlah kontaminasi telur Soil Transmitted Helminths pada lalapan mentah sebesar 27\%, dari sampel positif dtemukan 85\% telur Ascaris lumbricoides dan $15 \%$ telur cacing tambang. Hasil penelitian terhadap lalapan mentah menunjukkan bahwa angka kontaminasi telur Soil Transmitted Helminths masih cukup tinggi di daerah kecamatan Kebon Jeruk Jakarta.
\end{abstract}

Kata Kunci : kontaminasi, lalapan, Soil Transmitted Helmints

\section{ABSTRACT}

Infection of intestinal helminths cause many health problems.. Helminth transmission may occur via food/drinks or through the skin. In particular, consumption of raw vegetables allows for the transmission of helminth eggs to happen. The purpose of this study was to identify intestinal worm eggs in raw vegetables sold in warung pecel lele. Raw vegetables were usually served together with the pecel lele menu which is a very popular dish among the Jakartans. The present study is a descriptive study with a cross sectional approach. Seventy-four samples of raw vegetables were included in this study, which were obtained from 25 warung pecel lele in Kebon Jeruk District, Jakarta. Samples were examined for helminth egg contamination based on sedimentation method. Of all the raw vegetables samples, $27 \%$ was contaminated by soil transmitted helminths eggs. From the positive sample : Ascaris lumbricoides worm eggs were identified in $85 \%$, whereas hookworm eggs were found in 15\%. The study suggests that the number of helminth egg contamination identified in raw vegetables are still high among warung pecel lele in West Jakarta.

Keywords : contamination, raw vegetables, Soil Transmitted Helmints 


\section{PENDAHULUAN}

Penyakit cacingan masih merupakan masalah kesehatan masyarakat di Indonesia. Baik masyarakat pedesaan ataupun perkotaan sangat berisiko terinfeksi cacing usus. Banyak masalah kesehatan yang disebabkan oleh penyakit cacingan seperti penurunan fungsi kognitif (kecerdasan), malnutrisi (kurang gizi), gangguan pertumbuhan [1,2]. Salah satu penyebab tertularnya cacingan adalah seringnya mengonsumsi sayuran yang disajikan mentah (lalapan). Pada umumnya cacing yang menginfeksi sayuran (yang sering dijadikan lalapan) adalah cacing - cacing yang dalam daur hidupnya melalui tanah (Soil- Transmitted Helminths/ STH) seperti Ascaris lumbricoides, Ancylostoma, Trichuris trichiura [3]. Hal ini berhubungan dengan media tumbuh sayuran tersebut dan banyaknya daun yang bersentuhan dengan tanah dan sumber air untuk menyiram sayuran tersebut.

Di Indonesia, masyarakat terbiasa mengonsumsi sayuran yang disajikan secara mentah seperti lalapan, bahkan di daerah daerah tertentu, lalapan merupakan sajian yang selalu ada pada setiap hidangan makan. Sayuran merupakan sumber vitamin dan mineral bagi tubuh manusia. Sayuran akan lebih aman bagi kesehatan apabila dimasak dengan baik, sehingga semua kontaminan mati, selain itu sebelum dimasak, sayuran tersebut harus dicuci dengan air mengalir terlebih dahulu [4-7].

Pecel lele merupakan makanan yang sudah tidak asing lagi bagi kalangan masyarakat, banyak warung di Jakarta menyajikannya dengan harga yang terjangkau. Hampir di sepanjang jalan di daerah Kebon Jeruk terdapat penjual pecel lele. Pecel lele adalah makanan yang terdiri atas nasi, dengan lauk lele goreng dengan sambal dan lalapan sebagai tambahannya. Lalapan yang biasanya disajikan adalah kubis, kemangi, selada [1,6].

Berdasarkan latar belakang tersebut dilakukanlah penelitian ini dengan tujuan untuk mengetahui bahwa lalapan mentah yang disajikan pada warung pecel lele di Kecamatan Kebon Jeruk Jakarta Barat terkontaminasi telur cacing STH atau tidak, dan untuk mengetahui jenis cacing STH yang mengontaminasinya.

\section{METODE}

Penelitian ini bersifat deskriptif dengan pendekatan cross-sectional . Populasi penelitian ini adalah semua lalapan mentah yang disajikan di warung pecel lele di kecamatan Kebon Jeruk Jakarta Barat dengan teknik pengambilan sampel total sampling. Didapatkan 74 sampel lalapan dari 25 warung pecel lele.

Pemeriksaan sampel dilakukan di Laboratorium Parasitologi Fakultas Kedokteran dan Ilmu Kesehatan Universitas Kristen Krida Wacana.

Pemeriksaan sampel dilakukan dengan teknik sedimentasi. Lalapan mentah dipotong menjadi kecil-kecil kemudian direndam dengan 1 liter larutan $\mathrm{NaOH}$ 0,2\%. Diendapkan selama semalam. Hasil air rendaman didiamkan selama satu jam kemudian larutan bagian atas dibuang, larutan bawah disentrifugasi dengan kecepatan 1500 rpm selama lima menit. Larutan bagian atas dibuang. Endapan dibuat preparat sediaan langsung dengan menambahkan satu tetes lugol $1 \%$, kemudian diperiksa di bawah mikroskop. Di bawah mikroskop yag diamati adalah adanya telur cacing STH. Pengamatan dilakukan $3 \mathrm{x}$ untuk masing-masing sampel. Telur Ascaris lumbricoides tampak oval, berdinding tebal dengan tiga lapisan $[8,9]$. Telur cacing tambang (Ancylostoma, Necator) tampak bulat lonjong, berdinding tipis, di dalamnya terdapat beberapa sel $[8,9]$.

\section{Kaji etik}

Penelitian ini dinyatakan telah lolos kaji etik dengan nomor 771/SLKEIM/UKKW/FK/KE/V/2019 dari Komite Etik Penelitian Medis \& Kesehatan Fakultas Kedokteran Universitas Kristen Krida Wacana.

\section{HASIL PENELITIAN}

Hasil pemeriksaan laboratorium kontaminasi telur cacing STH pada lalapan mentah yang disajikankan warung makan pecel 
lele di Kecamatan Kebon Jeruk Jakarta, akan dijabarkan sebagai berikut :

Hasil identifikasi telur STH pada lalapan dihasilkan data yang dapat dilihat pada gambar 1.

kubis. Sebanyak 24 sampel lalapan kubis,

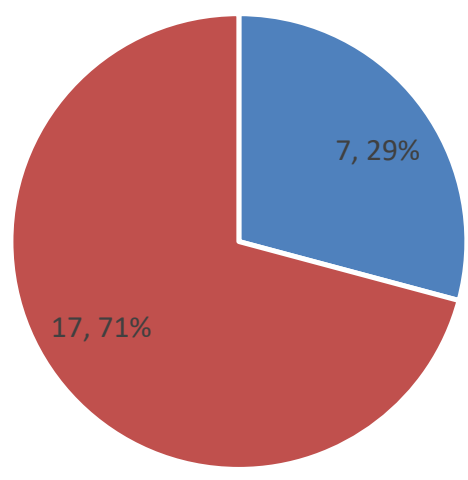

- Terkontaminasi (+) - Tidak terkontaminasi (-)

Gambar 1. Kontaminasi telur STH pada lalapan kubis

Dari tabel diatas, didapatkan bahwa jumlah kubis yang positif terkontaminasi telur STH sebanyak 7 sampel dan jumlah sayuran kubis yang tidak terkontaminasi telur STH sebanyak 17 sampel. Untuk prevalensi yang didapat adalah $\quad$ Prevalensi $=\frac{\sum \mathrm{f}}{N} \times 100 \% \quad=$ terkontaminasi $=\frac{7}{24} \times 100 \%=29.2 \%$.

Dalam penelitian ini, setiap sampel yang terkontaminasi dengan telur STH berdasarkan jenisnya. Didapatkan hasil untuk sayuran kubis yang dapat dilihat pada tabel 1.

Tabel 1. Frekuensi jenis kontaminasi telur STH pada lalapan kubis

\begin{tabular}{lcc}
\hline \multicolumn{1}{c}{ Yang ditemukan } & Jumlah & $\begin{array}{c}\text { Persentase } \\
(\%)\end{array}$ \\
\hline Telur Ascaris & 7 & 29.2 \\
lumbricoides & & \\
Tidak ditemukan & 17 & 70.8 \\
Total & 24 & 100 \\
\hline
\end{tabular}

Dari tabel diatas, didapatkan bahwa jenis telur Soil Transmitted Helminths yang mengkontaminasi lalapan kubis yang disediakan pada warung makan pecel lele di Kecamatan Kebon Jeruk Jakarta adalah telur Ascaris lumbricoides sebanyak 7 sampel. Sisanya tidak ditemukan telur STH yaitu sebanyak 17 sampel dari 24 sampel yang sudah dilakukan pengamatan melalui mikroskop. Untuk prevalensi yang didapat adalah telur Ascaris lumbricoides $=\frac{7}{24} \times 100 \%=$ $29.2 \%$.

Hasil identifikasi telur STH pada lalapan kemangi. Dalam penelitian ini, peneliti juga mengidentifikasi pada lalapan kemangi siap saji dibeli dari warung makan pecel lele yang menyediakan dan diidentifikasi sebanyak 25 sampel dan menghasilkan data yang dapat dilihat pada gambar 2 . 


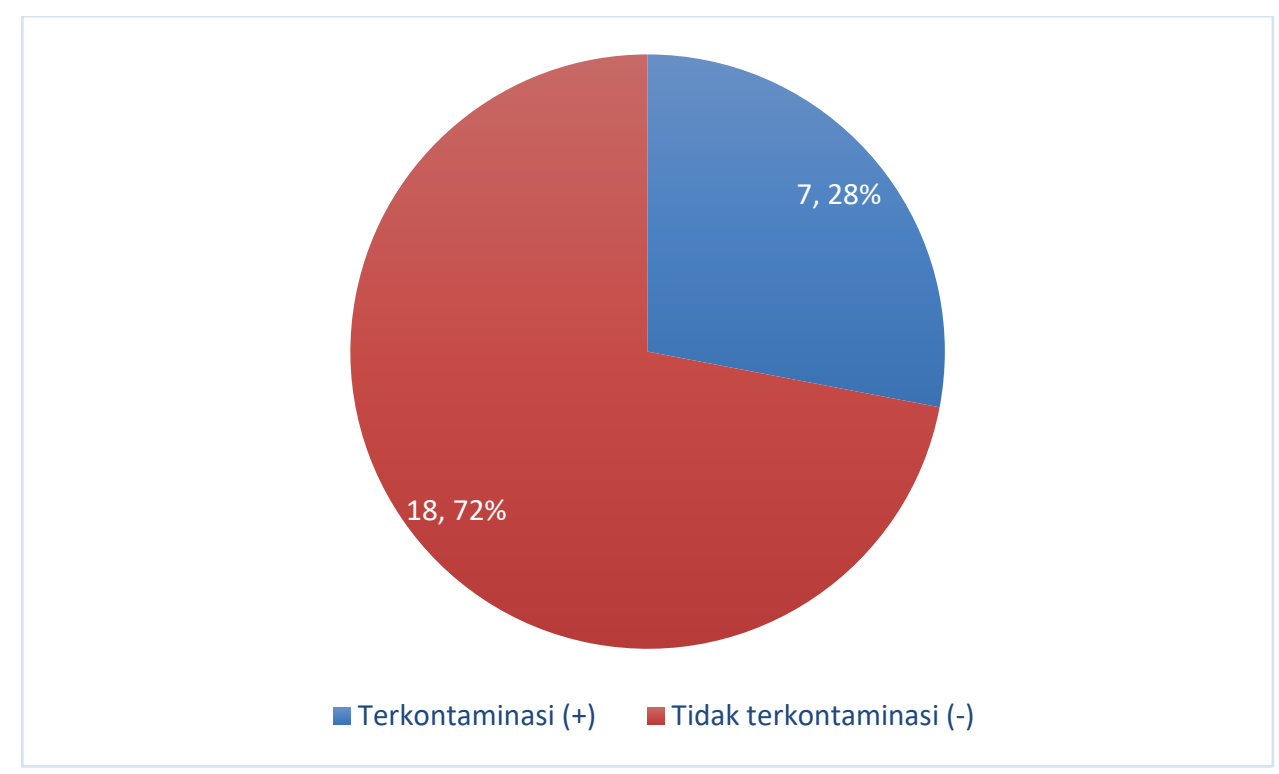

Gambar 2. Kontaminasi telur STH pada lalapan kemangi

Dari tabel diatas, didapatkan bahwa jumlah kemangi yang positif terkontaminasi telur STH sebanyak 7 sampel, dan jumlah lalapan kemangi yang tidak terkontaminasi telur STH sebanyak 18 sampel. Untuk prevalensi yang didapat adalah terkontaminasi $=\frac{7}{25} \times 100 \%=28 \%$.

Dalam penelitian ini, setiap sampel kemangi yang terkontaminasi dengan telur STH berdasarkan jenisnya didapatkan hasil seperti pada tabel 2 .

Tabel 2. Frekuensi jenis kontaminasi telur STH pada lalapan kemangi

\begin{tabular}{lcc}
\hline \multicolumn{1}{c}{ Yang ditemukan } & Jumlah & $\begin{array}{c}\text { Persentase } \\
(\%)\end{array}$ \\
\hline Telur Ascaris & 6 & 24 \\
lumbricoides & & \\
Telur cacing tambang & 1 & 4 \\
Tidak ditemukan & 18 & 72 \\
Total & 25 & 100 \\
\hline
\end{tabular}

Dari tabel diatas, didapatkan bahwa jenis telur Soil Transmitted Helminths yang mengkontaminasi sayuran kemangi yang disediakan pada warung makan pecel lele di Kecamatan Kebon Jeruk Jakarta adalah telur Ascaris lumbricoides sebanyak 6 sampel. Ditemukan telur cacing tambang sebanyak 1 sampel. Sisanya tidak ditemukan telur STH yaitu sebanyak 18 sampel dari 25 sampel yang sudah dilakukan pengamatan melalui mikroskop. Untuk prevalensi yang didapat adalah telur Ascaris lumbricoides $=\frac{6}{25} \times 100 \%=$ $24 \%$

dan telur cacing tambang $=\frac{1}{25} \times 100 \%=$ $4 \%$.

Hasil identifikasi telur STH pada lalapan selada. Dalam penelitian ini, peneliti juga mengidentifikasi pada lalapan selada siap saji dibeli dari warung makan pecel lele yang menyediakan dan diidentifikasi sebanyak 25 sampel dan menghasilkan data yang dapat dilihat pada gambar 3 . 


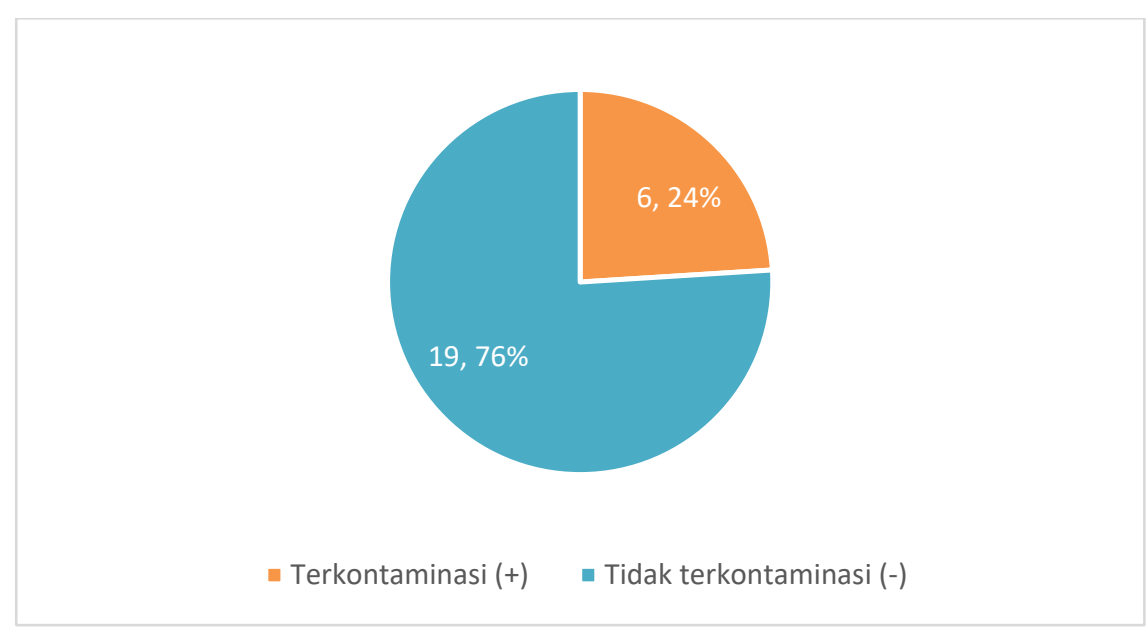

Gambar 3. Kontaminasi telur STH pada lalapan selada

Dari gambar di atas, didapatkan bahwa jumlah selada yang positif terkontaminasi telur STH sebanyak 6 sampel. Dan jumlah sayuran selada yang tidak terkontaminasi telur soil transmitted helminths sebanyak 19 sampel. Untuk prevalensi yang didapat adalah terkontaminasi $=$ $\frac{6}{25} \times 100 \%=24 \%$.

Dalam penelitian ini, setiap sampel selada yang terkontaminasi dengan telur STH berdasarkan jenisnya didapatkan hasil seperti pada tabel 3 .

Tabel 3. Frekuensi jenis kontaminasi telur STH pada lalapan selada

\begin{tabular}{lcc}
\hline Yang ditemukan & Jumlah & $\begin{array}{c}\text { Persentase } \\
(\%)\end{array}$ \\
\hline Telur Ascaris & 4 & 16 \\
lumbricoides & & \\
Telur cacing tambang & 2 & 8 \\
Tidak ditemukan & 19 & 76 \\
Total & 25 & 100 \\
\hline
\end{tabular}

Dari tabel di atas, didapatkan bahwa jenis telur STH yang mengontaminasi sayuran selada yang disediakan pada warung makan pecel lele di Kecamatan Kebon Jeruk Jakarta adalah telur Ascaris lumbricoides sebanyak 4 sampel (16\%). Ditemukan telur cacing tambang sebanyak 2 sampel. Sisanya tidak ditemukan telur Ascaris lumbricoides, telur Soil Transmitted Helminths sebanyak 19 sampel dari 25 sampel yang sudah dilakukan pengamatan melalui mikroskop. Untuk prevalensi yang didapat adalah Telur Ascaris lumbricoides $=\frac{4}{25} \times 100 \%=$ $16 \%$ dan Telur cacing tambang $=$ $\frac{2}{25} \times 100 \%=8 \%$.

Dalam penelitian ini, seluruh lalapan mentah (kubis, kemangi dan selada) yang diidentifikasi sebanyak 74 sampel telah dilakukan pengamatan dan menghasilkan data seperti pada gambar 4 . 


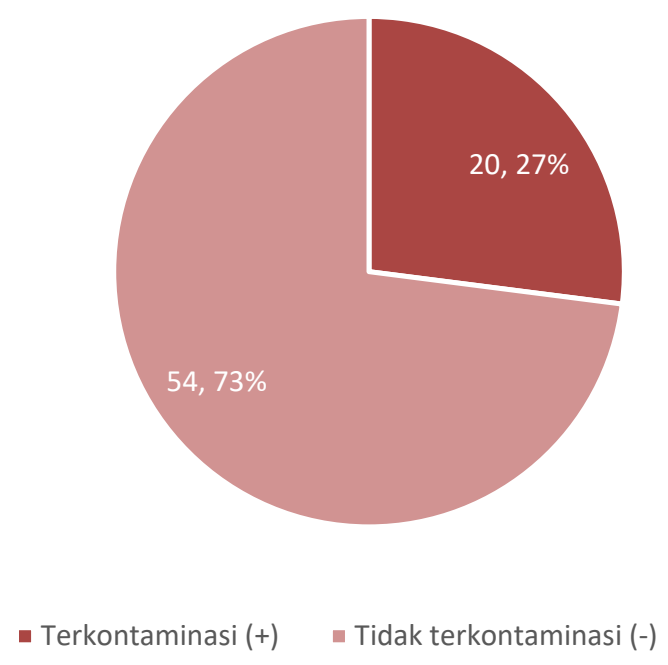

Gambar 4. Kontaminasi STH pada lalapan mentah yang disajikan pada warung pecel lele

Dari gambar diatas, ditunjukkan bahwa jumlah lalapan mentah yang positif terkontaminasi telur STH sebanyak 20 sampel (27\%). Dan jumlah lalapn mentah yang tidak terkontaminasi telur STH sebanyak 54 sampel (73\%).

Dalam penelitian ini, setiap sampel lalapan mentah yang terkontaminasi dengan telur STH berdasarkan jenisnya didapatkan hasil seperti pada tabel 4 .

Tabel 4. Frekuensi jenis kontaminasi telur STH pada seluruh lalapan mentah

\begin{tabular}{lcc}
\hline Yang ditemukan & Jumlah & $\begin{array}{c}\text { Persentase } \\
(\%)\end{array}$ \\
\hline $\begin{array}{l}\text { Telur Ascaris } \\
\text { lumbricoides }\end{array}$ & 17 & 85 \\
Telur cacing tambang & 3 & 15 \\
Total & 20 & 100 \\
\hline
\end{tabular}

Dari tabel di atas, didapatkan bahwa jenis telur STH yang mengontaminasi lalapan mentah yang disediakan pada warung makan pecel lele di Kecamatan Kebon Jeruk Jakarta adalah telur Ascaris lumbricoides sebanyak 17 sampel (85\%), ditemukan telur cacing tambang sebanyak 3 sampel (15\%).

\section{PEMBAHASAN}

Hasil dari tabel-tabel di atas menunjukkan bahwa Semua jenis lalapan mentah yaitu kubis (gambar 1), kemangi (gambar 3), selada (gambar 5) terkontaminasi oleh telur cacing STH. Diketahui kontaminasi telur STH pada lalapan mentah secara keseluruhan sebesar 27\% (gambar 4). Dari sampel yang positif terdapat $85 \%$ mengandung telur cacing Ascaris lumbricoides, telur cacing tambang sebanyak 15\% (tabel 4). Hasil ini penelitian ini serupa dengan penelitian yang dilakukan oleh Nashisha (2017) di Padang dan oleh Wardhana (2013) di Lampung prevalensinya hampir sama yaitu berkisar $26.2 \%$ $-38.1 \%[2,10]$.

Menurut Andrianto H. (2017), cara penularan telur cacing STH ke manusia melalui beberapa jalur, salah satunya memakan sayuran yang kurang matang, sayuran tidak bersih dicuci atau tidak dicuci/dikupas (dimana sayuran tersebut kemungkinan mengandung telur cacing) [11]. Angka prevalensi 27\% ini masih termasuk cukup tinggi mengingat risiko terjadinya transmisi telur cacing tersebut pada para konsumen. Jika sudah terjadi transmisi ke tubuh manusia maka telur cacing tersebut dapat melanjutkan siklus hidupnya, sehingga orang yang mengonsumsinya dapat terkena infeksi cacing yaitu menderita cacingan [8]. 
Salah satu hal yang mungkin memengaruhi kontaminasi telur STH pada lalapan mentah di penelitian ini adalah tempat atau asal dari lalapan mentah yang digunakan pedagang. Berdasarkan informasi yang diperoleh dari pemilik warung, lalapan mentah dibeli dari beberapa pasar tradisional di daerah Kebon Jeruk Jakarta seperti Pasar Musyawarah, Pasar Pagi, atau Pasar Taman Aries. Menurut penelitian yang dilakukan Almi (2011), sayuran lalapan yang dijual di pasar-pasar tradisional Kota Bandar Lampung memiliki angka kontaminasi telur Soil Transmitted Helminths yang cukup tinggi yaitu sebesar 72,7\% [2].

Peluang kontaminasi telur STH dipengaruhi oleh tingkat kebersihan dari pengolah makanan itu sendiri maupun cara mereka mengolah makanan. Berdasarkan informasi yang diperoleh dari pemilik warung, pedagang makanan mencuci lalapan mentah hanya dengan merendam lalu mengucek-ngucek di dalam ember, bukan dicuci dengan air mengalir. Telur STH mungkin saja sedikit terlepas dari lalapan mentah namun tetap berada di dalam ember dan tetap menggenang [5]. Selain itu perlu diperhatikan saat penyajian lalapan mentah pedagang juga tidak menggunakan sarung tangan ataupun mencuci tangan terlebih dahulu, sehingga memungkinkan risiko kontaminasi telur STH [10].

Pada penelitian ini, ditemukan kontaminasi telur cacing gelang (Ascaris lumbricoides) lebih banyak dari jenis lainnya (tabel 1, 2, 3, 4). Hal ini dikarenakan telur cacing gelang (Ascaris lumbricoides) memiliki ketahanan yang lebih baik di lingkungan. Telur Ascaris lumbricoides baru akan mati pada suhu lebih dari $40^{\circ} \mathrm{C}$ dalam waktu 15 jam sedangkan pada suhu $50^{\circ} \mathrm{C}$ akan mati dalam waktu satu jam. Pada suhu dingin, telur Ascaris lumbricoides dapat bertahan hingga suhu kurang dari $8^{\circ} \mathrm{C}$. Selain itu, telur Ascaris lumbricoides juga tahan terhadap desinfektan kimiawi dan terhadap rendaman sementara di dalam berbagai bahan kimia yang keras [2,6]. Selain itu telur Ascaris lumbricoides memunyai lapisan albuminoid yang diduga menyebabkan kelengketan pada daun sayuran.
Pada penelitian ini telur cacing tambang (Ancylostoma) ditemukan dalam jumlah sedikit, mungkin disebabkan oleh siklus kehidupan cacing tambang yang berbeda, berbeda pula cara infeksinya. Telur cacing tambang yang keluar bersama feses setelah 1-2 hari akan menetas menjadi larva, sehingga telur tidak ditemukan lagi di tanah [10]. Selain itu dinding telur cacing tambang yang tipis, sehingga mudah pecah.

Daun sayuran yang bergelombang seperti pada kubis (gambar 1 dan tabel 1) dan selada (gambar 3 dan tabel 3) dapat menyebabkan telur cacing STH sukar terlepas pada waktu pencucian. Demikian juga sumber air penyiraman pada waktu budi daya tanaman perlu diperhatikan.

\section{KESIMPULAN}

Hasil dari penelitian ini menunjukkan bahwa lalapan mentah yang disajikan pada warung pecel lele di daerah Kebon Jeruk Jakarta Barat, terkontaminasi oleh telur cacing STH dengan prevalensi 27\%. Dari sampel yang terkontaminasi didapatkan $85 \%$ oleh Ascaris lumbrocoides dan $15 \%$ cacing tambang.

\section{DAFTAR PUSTAKA}

[1] Nugroho C, Djanah SN, Mulasari SA. Identifikasi Kontaminasi Telur Nematoda Usus pada Sayuran Kubis (Brassica oleracea) Warung Makan Lesehan Wonosari Gunung Kidul Yogyakarta Tahun 2010. Jurnal Kesehatan Masyarakat Universitas Ahmad Dahlan. 2010; 4(1): $67-$ 75.

[2] Wardhana KP, Kurniawan B, Mustofa S. Identifikasi telur Soil Transmitted Helminths pada lalapan kubis di warungwarung makan Universitas Lampung. Medical Journal of Lampung University. 2014; 3 (3): 86 - 95.

[3] Wijaya J, Leonardo TL, Oktaviani, Puryadi. 2014 . Prevalensi dan Jenis Telur Cacing Soil Transmitted Helmints (STH) pada Sayuran Kemangi Pedagang Ikan Bakar di 
Kota Palu. Jurnal Buski. 2014; 5(2): 66-9.

[4] Dalimartha S, Felix A. Khasiat buah \& sayur. Depok: Penebar Swadaya; 2011: 128, 136-137.

[5] Suryani, D. 2012. Hubungan Perilaku Mencuci dengan Kontaminasi Telur Nematoda Usus pada Sayuran Kubis (Brassica oleracea) Pedagang Pecel Lele di Kelurahan Warungboto Kota Yogyakarta. KES MAS 2012; 6(2): 38-55.

[6] Astuti R, Siti A. Identifikasi telur cacing usus pada lalapan daun kubis yang dijual pedagang kaki lima di kawasan Simpang Lima Kota Semarang. Tersedia di https://jurnal.unimus.ac.id/index.php/psn 12012010 /article/ view/133/114. Diakses pada 1 September 2019

[7] Purba SF, Indra C, Irnawati M. Pemeriksaan Escherichia coli dan larva cacing pada sayuran lalapan kemangi (Ocimum basilicum), kol (Brassica oleracea L. var. capitata. L.), selada (Lactuca sativa L.), terong (Solanum melongena) yang dijual di pasar tradisional, supermarket dan restoran di kota Medan. Jurnal Ilmu Kesehatan Msyarakat. [Internet]. Tersedia pada https://jurnal.usu.ac.id/index.php/lkk/article /view/1136. Diakses pada 1September 2019

[8] Sutanto I, Ismid IS, Sjarifuddin, Sungkar S, editor. Buku ajar parasitology kedokteran. Jakarta: Edisi ke-4. Balai Penerbit FKUI; 2013: 6-24.

[9] Yotopranoto S, Sri HBS, Yoes PD. Atlas parasitologi kedokteran. Jakarta:

EGC; 2014: 3-15.

[10] Mutiara H. Identifikasi Kontaminasi telur Soil Transmitted Helminths pada makanan berbahan sayuran mentah yang dijajakan kantin sekitar kampus Universitas Lampung Bandar Lampung. J. Kedokt Unila.2015;5 (9): 20-46.

[11] Andrianto H. Kontaminasi Telur Cacing pada Sayur dan Upaya Pencegahannya. BALABA. 2017; 13 (2): 105-114. 